\title{
Land Assurance Process Execution Property Rights Of Indigenous Which Still In The Application Process Rights Used As Credit Guarantee
}

\author{
Daniel Budi Hardwianto ${ }^{1}$ and Akhmad Khisni ${ }^{2}$
}

\begin{abstract}
This study examines the weaknesses in the execution process guarantee of property rights of indigenous land is a wedge legal certainty between Debtor and Creditor. The study also describes some of the views that aims to provide a solution to a process execution guarantee of property rights of indigenous land is still in the process of increasing the rights as loan collateral. This study uses normative juridical research method, namely the use of library materials or secondary data as the basis for research related to the Security Law, Contract Law and Land Law, as well as interviews with several parties. This study is a study that aims to find the problems as a result of activities or programs that have been implemented or may be called as a research Prescriptive. Credit Guarantees of property rights in land there is very risky because there is no umbrella law on which the creditor to carry out the execution process if the Borrower defaults, so it is necessary rigor in the process of granting the Credit Guarantee. Indigenous land rights certainly has weaknesses in its status because it has not been registered at the land office. With the weakness and absence umbrella clear laws that, it needed the additional requirements of the creditors if it wants to receive Guarantee Credit in the form of land property rights of indigenous in order to guarantee legal certainty in the execution process guarantees, one of the solutions that can be taken is to increase the land status become ownership Right.
\end{abstract}

Keywords: Excecution Land Security; Indigenous Property Rights; The Application Rights; Credit Guarantees.

\section{Introduction}

Essential elements of a bank credit or financial institution is the confidence of bank financial institutions as creditors of the borrower as a debtor. The trust arises because, filled with all the terms and conditions for obtaining credit from banks or financial institutions (creditors) by the debtor. The significance of these beliefs is the belief of banks or financial institutions as creditors that the loans will be earnest readmitted within a certain time period according to the agreement. ${ }^{3}$

Their individual ownership of land becomes more meaningful in the value of Capital Asset, one of which can be pledged as collateral for a loan. However, land property rights as collateral the credit on his credit when credit tailgate jammed, then the consequences be repayment of the loan, that is by cashing in what the credit guarantee itself in this case is the land which collateralized.

In general, the Act has provided guarantees or protection to creditors, as stipulated in Article 1131 of the Civil Code, namely:

"All the assets of the Borrower, whether moving or not moving, both at present and that will be no later become dependent / guarantees on their debts ". Guarantee under

\footnotetext{
${ }^{1}$ Student of Master Program in Notary Program UNISSULA email daniel.rembol@gmail.com

2 Lecturer of Faculty of Law UNISSULA

${ }^{3}$ Hermansyah 2008 Hukum Perbankan Nasional Indonesia Kencana Prenada Media Jakarta p. 43.
} 
Article 1131 of the Civil Code the general nature or in other words the object guarantee is not specifically designated and not designated for a creditor certain, therefore, if the guarantee is sold then the result is divided equally according to the size of the individual receivable Creditors (konkurent).

However, in the absence of competition in the business world financial institutions of course there are a few companies of financial institutions that receive collateral in the form of land property rights of indigenous used as collateral, we need to know that the actual land property rights not being recognized as a form of legal title to land but only as a form of land tenure alone so that if will be made in credit guarantees would be constrained in the process of execution.

Based on that later raised the issue, which sometimes debtors to borrow against the land property rights of indigenous many banks or financial institutions do not receive land for certified to be used as collateral, unless the collateral of land that has not been certified it made the power of attorney to take care of manufacture of rights certificate by the bank or at the same time the rights are registered improvement process credit agreement, and continued with the Power of Attorney Imposing Mortgage after the certificate completed. However, banks' lending and financing, particularly smaller banks such as Bank Rural folk financing bank or sharia, they receive a guaranteed land for the certified. Based on all of the existing reality,

With the explanation above, for the land property rights of indigenous who are not registered or are in the form of booklets $C$ village certainly has not been able to be burdened Mortgage, this is where considerations become an obstacle for the creditor to be able to channel funds to the debtor. This is because lenders will have difficulty in excecution guarantees are still a land of Indigenous Lands Properties such as books has $C$ village because there is no such guarantee executorial power that has been installed Mortgage.

With the problems that occur on many banks or financial institutions to make a judgment when many will be binding guarantee in the form of traditional land property rights, among others Character, Capital, Capacity, and Collateral Condition. Surely Collateral as the final step in the consideration of providing credit.

Based on all of the fact that there is such, it is considered that the above problem is a problem that is very interesting to discuss and study that aims to determine how the process of execution of collateral Land Property Rights of Indigenous still in the application process rights were used as loan collateral in creating legal certainty for each interest party.

\section{Research Methods}

In an effort to collect data in order to discuss the issues raised in this legal research method normative juridical namely by using secondary data, namely the use of library material as a base research, obtained through library research related to understanding the Law of Guarantees, Contract Law and Land Law.

According to Soerjono Soekanto normative legal research or normative legal research literature that is done by researching library materials or secondary data 4 ,

\footnotetext{
${ }^{4}$ Soerjono Soekanto dan Sri Mamudji 2001 Penelitian Hukum Normatif Suatu Tinjauan Singkat Edition 5 PT. Raja Grafindo Persada Jakarta p. 13.
} 
This study is a study that aims to to find problems as a result of activities or programs that have been implemented or may be called as a research prescriptive is "a research which aims to provide solutions or suggestions to solve the problems" 5

Based on the explanation above, the kind of research that the author used in the preparation of this paper is a normative legal research or legal normative. The juridicallegal materials, interviews or data are then arranged systematically, examined, and then be deduced.

\section{Results And Discussion}

\subsection{The weakness of the execution guarantee of property rights of indigenous land.}

In banking practice, the guarantee of a general nature is not given legal protection (less raises security) to guarantee credit extended. Banks require collateral appointed and tied in particular to guarantee the debt of Debtor and only applies to the bank. This guarantee is known as a special guarantee that arise because of a special agreement between the Lender and the Borrower. Usually with collateral such as land which is then saddled with Mortgage as collateral for credit to this bank. Guarantee to provide protection for the lender in case of default or breach of contract. The notion of default by Yahya Harahap: "Default as the implementation of the obligations that are not on time or do not think properly,

Agreement with Bank debts, usually using Mortgage institution as collateral for a loan from Mortgage Debitor. The right itself is a security interest for repayment of debt, where the debt guaranteed should a particular debt.

Under the terms of Article 1 (1) of Act No. 41996 is the Encumbrance is: Mortgage on land and objects relating to soil, hereinafter called Mortgage is a security interest that is charged to the land rights referred to by Act No. 5 of 1960 on Basic Regulation of Agrarian Principles, following or not following other objects that are installed on the ground, for the repayment of certain debt, which gives precedence to the position that certain creditor to creditor-other creditors.

Given some of the explanation of the credit agreement on many small businesses who can not enjoy the policy of the government in terms of additional working capital due to the limitations of the requirements that must be met in order to obtain a capital injection of credit to be disbursed by the banks one of which is the limited warranty, this is because small businesses to the area in the regency or city in Indonesia in the ownership of land or a house is still in the form of customary property rights or that is more familiar with a book called $C$ village or Letter $D$, While some existing banks or financial institutions are willing to accept collateral in the form of land is still shaped property rights of indigenous and also there that do not accept and if acceptable course with some specific considerations.

Indigenous property rights in the form of a book of this village $\mathrm{C}$ obtained from the village office or village where the land is located, village $C$ book is proof in the form of notes that are in the Office of the Village / Sub. Regarding the book C village called ledger or village office or village, in the community are still many who do not

${ }^{5}$ Sri Mamuji et.al. 2005 Metode penulisan dan Peneliatain Hukum Jakarta : Badan penerbit Fakultas Hukum Universitas Indonesia p 4. 
understand what is meant by a book or ledger C village, because in the literature or legislation on land is rare to be discussed or presented. Regarding book or ledger $\mathrm{C}$ village is actually only used as a basis for the record tax collection. Description of the land is in the village $C$ book is far from complete and not in detail how the recording and the majority of the notification between villages or village office is a distinct possibility,

In addition to the authors are interested to know more about the strength of the $\mathrm{C}$ book excerpt village in obtaining land rights received. The note of procedure $\mathrm{C}$ book contained village office held by the village headman. Society as holders of land rights have evidence in the form "girik" as evidence of tax payment on the ground. "Girik" people familiar with it as evidence of land ownership "girik" whereas it is proof of tax payment on the ground.

Given the importance of customs registration of property rights to land as proof of ownership of land rights legally in accordance with Article 23, Article 32 and Article 38 of the Basic Agrarian Law (BAL), then given an obligation to register the customary lands of indigenous property rights in particular. But the reality is not optimal, it may be the legal certainty of land on land registration.

In Article 19 BAL government to provide land registration throughout the territory of the Republic of Indonesia, attributable to the lack of knowledge, awareness about the proof of ownership of land belonging to indigenous the land. They assume the ownership of the citation "girik" C book village located in the Village / Village is evidence of legal ownership. It still the transfer of rights such as trade, grant, inheritance or deeds are not registered already happened between basic rights acquisition of "girik" and still mutation "girik"based by deeds, without registered at the Land Office.

Land rights of indigenous yet has solid evidence in the status of land ownership in Indonesia that can be bound to a guarantee by the Mortgage, according to the laws and regulations that has right priority as the receiver of guarantees under Act No. 4 of 1996 is the Power of Attorney Imposing Mortgage (SKMHT), Deed of Encumbrances Encumbrance (APHT) for land that can be attached to the land security status Property Rights (HM), Right to Build (HGB), Used Right (HGU), and the Right of Use (HP) on the State land .This led to the bank seeks to provide credit guarantee "safe" without fear of being sued by a third party or other creditors who filed a lawsuit before the debtors pay off its debts. ${ }^{6}$

Although the absence of the rule of law on the ground that has not been certified as collateral, banks and borrowers still make the land to be used as guarantee, because it becomes a question of how the power law of the land has not been certified / "girik" as the object of the collateral in a debt financing. On the other hand, the parties in the provision of loans with collateral, which guarantees submitted by the debtor is the land, then the land as collateral is land that has been certified. This is because there is no official security agency for land that has not been certified. With the entry into force of the BAL dated 24 September 1960 concluded with the diversity of the "agrarian reform" which includes areas of land law. BAL and its

\footnotetext{
${ }^{6}$ Munir Fuady 1999 Hukum Perbankan Modern Bandung: PT. Citra Aditya Bakti
} 
implementing regulations is a single National Land Law for all the land in the region Indonesia ${ }^{7}$

In order to hold a unification law of the land, provided security interests in the new land, which was given the name Encumbrance, in lieu of hypotheek institutions and Credietverband, using Property Rights of land, leasehold and Broking as an object that can thrusted. But during the 35 years since the enactment of the BAL, institutions Encumbrance can not function properly because there are no set rules in full, as required by section 51 of the BAL. For a while as provided in article 57 of the BAL, as long as laws are intended not yet formed, can be used provisions and provisions Hypotheek Credietverband. So, in practice encountered two kinds of mortgage, the Mortgage who invoke the provisions hypotheek. ${ }^{8}$,

In practice in the world of micro-finance institutions in particular pretty much willing to accept collateral in the form of land property rights of indigenous, this is due to high competition in the financial institutions so that most of the institutions of the financial ended up taking the SME segment which needs capital but only a discount Land customary property rights used as collateral.

But on the other hand have an economic value but the economic value of the has a large risk for the lender, this is because that the land property rights of indigenous do not yet have the force of law is strong, because their land property rights of indigenous can not install the security rights and land that can be installed right dependents by Act No. 4 of 1996 is the Power of Attorney Imposing mortgage (SKMHT), Deed of Encumbrances Encumbrance (APHT) for land that can be attached to the land security status Property Rights (HM), Right to Build (HGB), Rights (HGU), and the Right of Use (HP) on State land.

Mortgage on land and objects relating to soil, hereinafter called Mortgage, is a security interest that is charged on land rights as stipulated in Act No. 5 of 1960 on Per-rules Basic Agrarian, following or the following are not other objects which constitute a Case-host with the land, for the repayment of certain debt, which gives precedence to the position of certain creditors to other creditors; so there is a sense of security in lending by the financial institutions.

In Article 51 of Act No. 5 of 1960 on Basic Regulation of Agrarian which is also called the Law of Agrarian Affairs, has provided the right institutions strong assurance that can be imposed on the right to land, ie Mortgage, instead of the institution hypotheek and Credietverband. ${ }^{9}$

Since enactment of the Basic Agrarian Law, Mortgage above institutions can not function properly, because there are no laws that govern it completely, as desired by the provisions of Article 51 of the Act. During that period, based on transitional provisions contained in Article 57 of the Basic Agrarian Law, was enacted provisions hypotheek referred to in Book II Book of the Law of Civil Law Indonesia and the provisions of the Statute Credietverband 1908-542 as amended by Staatsblad 1937190, all the things that there are no provisions in or under the Basic Agrarian Law.

\footnotetext{
7 Boedi Harsono (2) 2007 Towards Completion of the National Land Law Jakarta: University Trisakti p.4-5.

${ }^{8}$ Ibid p. $134-135$

${ }^{9}$ A common explanation of Act No. 4 of 1996 on Mortgage of Land and Their Bodies Relating to Land
} 
The provisions of the legislation above is derived from the Dutch colonial era and is based on the land law in force before the Land Law National, as everywhere points of provisions contained in the Law on Agrarian and is intended to be only temporary, that pending the establishment of the Act referred to in Article 51 above.

Therefore, the provisions are clearly incompatible with the principles of the National Land Law and in fact can not accommodate developments in the field of credit and guarantee rights as a result of the construction of economic progress. The result is the emergence of different views and interpretations of the various problems in the implementation of the law bail on the ground, for instance regarding the inclusion of executorial title, execution and so forth, so that the legislation is less ensuring legal certainty in lending activities.

With the above description object property rights over indigenous lands not included in it so it does not has much the strong law, in accordance with the Basic Law of Agrarian followed up by the Government Regulation No. 10 of 1961 which was later replaced by Government Regulation No. 24 of 1997 is not possible again issued rights that are subject to the Civil Code or who will submit to the local customary Law except to explain that these rights are indigenous rights. Given the importance of registration of property rights over indigenous land as proof of ownership of land rights legally in accordance with Article 23, Article 32 and Article 38 of the Basic Law of Agrarian, then given a duty to register customary land especially property rights of Indigenous in order to have the power a strong law.

Property rights of indigenous land security that have not been converted into certificates of course very difficult has executed if used as collateral in lending because there is no legal umbrella.

\subsection{The Process of Executing The Guarantee Of Property Rights of Indigenous Land Is Still In The Process Of Increasing The Rights As Loan Collateral}

Execution process guarantees customary freehold land is not yet a strong legal regulation so it is difficult to be executed due to the creditor or holder has no right preverent guarantee and does not have the right excecutorial as attached to the security right.

In practice the process of lending, which uses indigenous land rights guarantees in financial institutions one of them PT. Bentara Sinergies Multi Finance shall be eligible in order to ensure legal certainty for the creditors, the interview with Mr. Bagus Burhan, who served as Head of Credit Analyst Central Java Regional Work Units Micro Division PT. Bentara Sinergies Multi Finance Solutions in order to guarantee indigenous land rights can be exercised as loan collateral shall be enhanced first course land ownership status or converted into land property rights,

In an interview with Mr. Bagus Burhan that in analyzing the guarantee of property rights of indigenous land that must fulfill, namely the provision of credit requirement ${ }^{10}$ :

- Land Book Excerpts must attach Letter $\mathrm{C}$ of the village (the original)

- Must attach a history of land ownership of indigenous property rights issued by the local village chief up to the District.

10 Credit Analyst Interview Regional Head of Central Java Micro Working Unit Division PT. Bentara Sinergies Multi Finance Bagus Burhan December 12017 
- Required to include a statement of the owner of land customary property rights are not in dispute

- There is a block from the local village head stating that the land is secured to the PT. Bentara Sinergies Multi Finance.

Interest above requirements necessary to ensure legal certainty at least the land in question is already listed in the local district office because the village head is the competent authority as the holder Books Letter C or proprietary rights of customary land has an important role with regard to the transfer of rights to land, besides that as head of the region and is considered as a man who knows the condition and status of the land.

By sticking Mortgage in such guarantees then in accordance Act No. 4 of 1996 Article 6 which reads "If the debtor in default, the holder of Encumbrance first has the right to sell the object of Encumbrance on its own power through a public auction, and take repayment of its receivables from the sale proceeds . "On the basis of these facts, then the lender has preferent rights, namely:

- Provide preferred position or to the holder;

- Always follow the pledged object in the hands of whoever the object is;

- Meet the principle of specialty and publicity so as to bind third parties and provide legal certainty to the parties concerned;

- Easy and sure execution of execution.

If the creditor has a certificate of encumbrance of course it would be easy in the process excecution namely through State Property Office and Auction (KPKNL) in accordance Minister of Finance Regulation No. 170 / PMK.01 / 2012 concerning Organization and Work Flow Vertical Institutions Directorate General of State, that KPKNL has the task to carry out services in the field of state assets, assessment, state receivables and auction.

\section{Closing}

\subsection{Conclusion}

- From the financial institutions credit distribute to borrowers who take out insurance in the form of customary land property rights that are required to embed the principles of credit ratings "5 C's", namely: Character, Capital, Capacity, Condition of Economic and Collateral. So the financial institutions another aspect of the aspects of the new and the last one to consider aspects of the guarantee, as well as providing education to the debtor on the status of customary land rights that have not been perfect in their ownership status.

- In consideration of the above considerations if it can work in harmony and pressing the ownership status of the land in the form of property rights are indigenous to a low number, or in other words the majority of Indonesian people have the land certificate in the form of certificates of property rights course in the world of business in financial institutions will be more secure and there is legal certainty for each party. 


\subsection{Sugestion}

In terms of research on the author wants to give advice to the government that the government should support the entire audience Indonesian citizen who is still pick the land is still in the form of property rights are customary to be converted en masse in order to the future of the people pick the right status katas strong ground and is protected by law, it is now the president has launched a program of the National Agrarian Operations Project (Prona) but has not been evenly distributed, that program authors hope can be accomplished and felt by all citizens of Indonesia.

\section{Bibliography}

[1] A common explanation of Act No. 4 of 1996 on Mortgage of Land and Their Bodies Relating to Land

[2] Boedi Harsono (2) 2007 Menuju Penyempurnaan Hukum Tanah Nasional Jakarta: Universitas Trisakti.

[3] Hermansyah 2008 Hukum Perbankan Nasional Indonesia, Kencana Prenada Media, Jakarta.

[4] Munir Fuady 1999 Hukum Perbankan Modern Bandung: PT. Citra Aditya Bakti .

[5] Soerjono Soekanto dan Sri Mamudji, Penelitian Hukum Normatif Suatu Tinjauan Singkat Edition 5 PT. Raja Grafindo Persada, Jakarta.

[6] Sri Mamuji et.al. 2005 Metode penulisan dan Peneliatain Hukum Jakarta: Badan penerbit Fakultas Hukum Universitas Indonesia.

[7] Credit Analyst Interview Regional Head of Central Java Micro Working Unit Division PT. Bentara Sinergies Multi Finance, Bagus Burhan, December 12017 